\title{
Influence of pH on Structural, Morphological, Optical, Photocatalytic, and Antibacterial Properties of Yttrium Oxide Nanoparticles via Co-Precipitation Method
}

\section{Kiruthika Parangusan}

PSG College of Arts and Science

Venkat Subramanium ( $\square$ venkatnanotechnology@gmail.com )

PSG College of Arts and Science

Lakshmanaperumal Sundarabharathi

S.S. Duraisamy Nadar Mariammal College

Karthik Kannan

Kumoh National Institute of Technology

Devi Radhika

Jain-Deemed to be University

\section{Research Article}

Keywords: Yttrium oxide, co-precipitation method, MB dye, foodborne pathogens

Posted Date: April 8th, 2021

DOI: https://doi.org/10.21203/rs.3.rs-385905/v1

License: (c) (i) This work is licensed under a Creative Commons Attribution 4.0 International License.

Read Full License 


\title{
Influence of pH on structural, morphological, optical, photocatalytic, and antibacterial properties of yttrium oxide nanoparticles via co-precipitation method
}

\author{
Kiruthika Parangusan ${ }^{1}$, Venkat Subramanium ${ }^{1 *}$, Lakshmanaperumal Sundarabharathi ${ }^{2}$, \\ Karthik Kannan ${ }^{3}$, Devi Radhika ${ }^{4}$ \\ ${ }^{1}$ Department of Electronics, PSG college of Arts and Science, Coimbatore, Tamil Nadu, India \\ ${ }^{2}$ Department of Physics, S.S. Duraisamy Nadar Mariammal College, Kovilpatti, Tamil Nadu,
} India.

${ }^{3}$ School of Advanced Materials Science and Engineering, Kumoh National Institute of

Technology, 61 Daehak-ro, Gumi-si, Gyeongbuk 39177, Republic of Korea

${ }^{4}$ Department of Chemistry, School of Engineering and Technology, Jain-Deemed to be

University, Jakkasandra, Ramnagara-562112, Karnataka, India.

\section{Abstract}

*Corresponding author: venkatnanotechnology@gmail.com

Yttrium oxide nanoparticles with multiform morphologies have been synthesized by the coprecipitation method. The structure, morphology, functional groups, optical and photoluminescence properties were examined through X-ray diffraction (XRD), Scanning electron microscope (SEM), Fourier transform infrared spectrometer (FTIR), UV-Visible (UVVis), Photoluminescence spectra (PL). The XRD patterns obtained for the samples synthesized at various $\mathrm{pH}$ values confirmed the cubic structure of $\mathrm{Y}_{2} \mathrm{O}_{3}$. The patterns obtained on the samples at $\mathrm{pH}$ values of 8 and 9 appeared as have sharp peaks suggested, that the samples were well crystallized. From UV-vis spectra, it revealed that the bandgap energy exhibits a blue shift in the absorption edge for the samples with the increase of $\mathrm{pH}$ due to their changing morphologies and surface structures. In the PL spectra, the obtained $\mathrm{Y}_{2} \mathrm{O}_{3}$ samples demonstrate an intense and bright UV and blue emission under the excitation wavelength range of $250 \mathrm{~nm}$. The photocatalytic degradation of the $\mathrm{Y}_{2} \mathrm{O}_{3}$ nanostructure was studied against the Methylene blue (MB) dye under sunlight irradiation. The results showed good recital under solar light irradiation. Further, the antimicrobial activities of $\mathrm{Y}_{2} \mathrm{O}_{3}$ nanostructure against foodborne pathogens (Staphylococcus aureus and Salmonella typhi) were examined by using the disc diffusion method. Moreover, the $\mathrm{Y}_{2} \mathrm{O}_{3}$ nanostructure was found to be biocompatible.

Keywords: Yttrium oxide; co-precipitation method; MB dye; foodborne pathogens. 


\section{Introduction}

Currently, tremendous efforts have been focused on the studies of modern nanomaterials and their impending applications. With increasing industrial demands, it exhibits a smaller size, well crystalline nature, and better nanostructures adopted for electronic devices and wastewater remediation applications. Rare earth metal oxide nanoparticles are extensively studied in the field of nanomaterials due to their peculiar nanostructures, optical, electronic, and catalytic properties [1]. All these features are favorable to several technological applications like as optical communication, optical display device, photocatalytic, medical diagnosis, and UV shielding [1-7]. In addition, Fluorescent based nanomaterials versatile role in the area of UV and visible light emission devices $[8,9]$. The compounds based on rare earth metals have been widely utilized as high recital luminescent materials, because of their properties within the nanoscale range might be related to their morphology $[10,11]$. Among all rare-earth oxides, yttrium oxide $\left(\mathrm{Y}_{2} \mathrm{O}_{3}\right)$ nanoparticles have also been significantly reviewed as a host material that used upconversion efficiency because of their extensive range of optical transparency large bandgap $(5.8 \mathrm{eV})$ and other optical and biological applications $[12,13]$.

The morphology and structure of materials chiefly depend upon the fabrication circumstances and limitations [14]. So far, numerous techniques employed for the fabrication of $\mathrm{Y}_{2} \mathrm{O}_{3}$ nanostructures, such as sol-gel [15], hydrothermal [16], and combustion synthesis [17]. Amid these, the co-precipitation route extends renowned benefits counting sample purity, low cost, and eases to production. In this method, the preparation of particles is below hundred nanometers, easily control the particle size by changing the hydrolysis time and regulate the shape of the particles by changing the $\mathrm{pH}$ value of the aqueous solution [18]. This size control and shape are desirable to generate well optoelectronic material. Hence, in this work synthesize $\mathrm{Y}_{2} \mathrm{O}_{3}$ nanoparticles with well-ordered particle size and shape by the trouble-free alteration of the $\mathrm{pH}$ value of the solution. The manipulate of $\mathrm{pH}$ on the purity, crystallinity, morphology, optical, and emission properties has been investigated through XRD, FTIR, SEM, UV-Vis, photoluminescence, photocatalytic and biological studies. 


\section{Experimental}

\subsection{Synthesis of yttrium oxide nanoparticles}

Yttrium oxide nanoparticles were synthesized by the co-precipitation route. The initial chemicals consumed in this process were of analytical grade without any supplementary cleansing. The yttrium nitrate hexahydrate $\left(\mathrm{Y}(\mathrm{NO})_{3} \cdot 6 \mathrm{H}_{2} \mathrm{O}\right)$ was used as a forerunner material and ammonium hydroxide employed as a precipitating agent (varying $\mathrm{pH}$ values). Then, the precise amount of yttrium nitrate was suspended in $50 \mathrm{~mL}$ of deionized water (DD) and stirred well through a magnetic stirrer. The $\mathrm{pH}(7,8$, and 9) readings of the solution were separately regulated by ammonium hydroxide; the above were combined through steady stirring for $2 \mathrm{~h}$ at $353 \mathrm{~K}$. Finally, the white precipitate was obtained. The accomplished precipitate was filtered off and cleaned a several times with DD and ethanol. The resultant white gel was dehydrated at $353 \mathrm{~K}$ for approximately $3 \mathrm{~h}$ in a hot air oven and next calcinated at $773 \mathrm{~K}$ for $2 \mathrm{~h}$.

\subsection{Characterization techniques}

The phase of the fabricated samples were examined by XRD operating the PANalytical model X'PERT-PRO spectrometer $\mathrm{K}_{\alpha}$ radiations $(\lambda=1.5418 \AA$ ). FTIR spectra were recorded using the Shimadzu model $8400 \mathrm{~S}$ spectrometer $\left(4000 \mathrm{~cm}^{-1}\right.$ to $\left.400 \mathrm{~cm}^{-1}\right)$. For this analysis, a small amount of $\mathrm{Y}_{2} \mathrm{O}_{3}$ samples was blended with $\mathrm{KBr}$ and then pressed into pellets for the measurement. The changes in surface morphology of the products were observed by (SEM, S-4200, Hitachi) functioned at $15 \mathrm{kV}$. The UV-vis absorption spectra were obtained on the Agilent 8453 diode array UV-Vis spectrophotometer. Photoluminescence was examined on a Cary eclipse spectrophotometer with a UV light as the excitation light source.

The photocatalytic action of the $\mathrm{Y}_{2} \mathrm{O}_{3}(\mathrm{pH}=9)$ was appraised by handling a strategy interpreted in [35] although the antibacterial action of the $\mathrm{Y}_{2} \mathrm{O}_{3}(\mathrm{pH}=9)$ was explored by agar well diffusion method portrayed elsewhere [35].

\section{Results and Discussions}

\subsection{Structural analysis}

The XRD peaks of yttrium oxide nanoparticles with various $\mathrm{pH}$ values that were different from 7 to 9 are revealed in Fig. 1 . The peaks at $2 \theta$ values of $20.49^{\circ}, 29.119^{\circ}, 33.75^{\circ}, 39.25^{\circ}, 43^{\circ}$, 
$48.46^{\circ}$, and $57.56^{\circ}$ relate to the (211), (222), (400), (332), (134), (440) and (622) crystal planes and it verifies the cubic structure of $\mathrm{Y}_{2} \mathrm{O}_{3}$. The obtained peaks of all fitted with the customary JCPDS card [89-5591]. No secondary peaks (unwanted impurities) are noticed in the XRD, which designates that are highly phase pure compounds. At the optimum value of $\mathrm{pH}$, supersaturation becomes the highest value and the radius of crystallites will be formed as a lowest, which is due to the circumstance that larger concentration of solute (supersaturation) guides to the initiation of a huge numeral of nucleation sites and more nuclei means smaller sized nuclei. For $\mathrm{pH}$ values 8 and 9 of the samples, more sharp peaks obtained which suggested that the synthesized samples were highly crystallized. Though, the $\mathrm{Y}_{2} \mathrm{O}_{3}$ nanoparticles achieved from the solution of $\mathrm{pH}=7$ revealed reasonably less crystallinity and crystallite size. Fig. 1 exhibits a slightly broad peak for $\mathrm{pH}=7$ and 8 which results from diminished crystallite size contrasted to the higher value of $\mathrm{pH}=9$ illustrated in Table 1 .

The average crystallite size (Debye-Scherrer) of yttrium oxide nanoparticles was attained by this equation 1 [19]

$$
D=\frac{0.9 \lambda}{\beta \cos \theta}
$$

Where ' $\beta$ ' signifies the full width at half maximum (FWHM) of XRD peaks, ' $\theta$ ' is the Bragg's angle of diffraction lines, ' $\lambda$ ' is an incident wavelength of $\mathrm{X}$ - rays. The crystallite size is measured from the XRD and it is found to be 13 - $16 \mathrm{~nm}$ which was displayed in Table 1. For cubic structure, the Lattice constant (a) is obtained from $\mathrm{d}_{\mathrm{hkl}}$ as given below

$$
\frac{1}{d^{2}}=\frac{h^{2}+K^{2}+l^{2}}{a^{2}}
$$

Where ' $\mathrm{d}$ ' is the Inter planar spacing, (h k l) is the Miller indices and ' $a$ ' is Lattice constant. The calculated lattice value is $10.6020 \AA$ and it is in fine conformity with the customary JCPDS card no- 89-5591. 


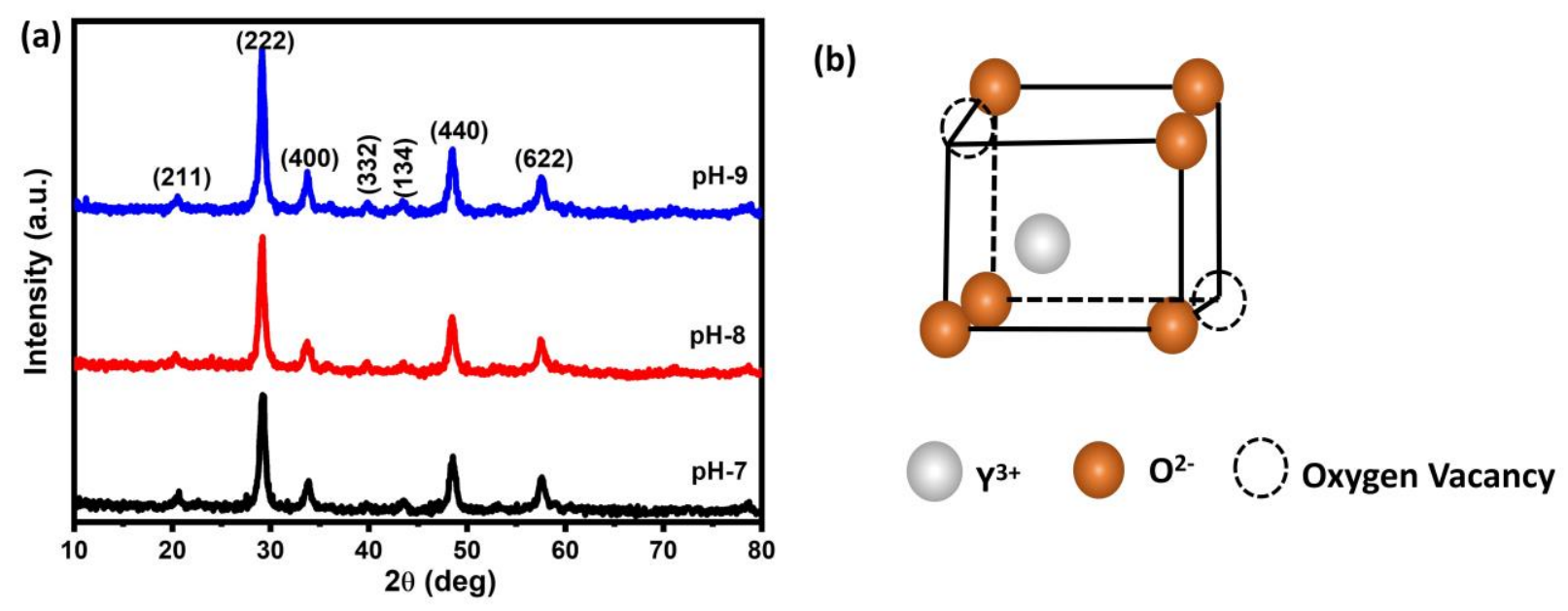

Fig.1. XRD patterns of $\mathrm{Y}_{2} \mathrm{O}_{3}$ nanoparticles prepared with different $\mathrm{pH}$ values

The surface states will take part in a key function in the nanoparticles, because of their huge surface to volume ratio with a lessening in crystallite size [20]. The specific surface area is calculated by using the formula,

$$
S=\frac{6 \times 10^{\mathrm{a}}}{D_{p} \rho}
$$

Where ' $S$ ' is the specific surface area, ' $\mathrm{D}_{\mathrm{p}}$ ' is the particle size and ' $\rho$ ' is the density of $\mathrm{Y}_{2} \mathrm{O}_{3}\left(5.01 \mathrm{~g} / \mathrm{cm}^{-3}\right)$. The specific surface area of $\mathrm{Y}_{2} \mathrm{O}_{3}$ nanoparticles depends on the association amid crystallite size and shape. The dislocation density strongly influences many material properties including strength, size, and defects. The evaluated dislocation density for $\mathrm{Y}_{2} \mathrm{O}_{3}$ nanoparticles has shown in Table 1.

\section{Table 1}

Variation of lattice constants, crystallite size, and energy bandgap of $\mathrm{Y}_{2} \mathrm{O}_{3}$ nanoparticles synthesized at different $\mathrm{pH}$ values. 


\begin{tabular}{|c|c|c|c|c|c|c|}
\hline Samples & $\begin{array}{c}\text { Average } \\
\text { crystallite size } \\
\text { (D) in } \mathbf{~ n m ~}\end{array}$ & $\begin{array}{c}\begin{array}{c}\text { Lattice } \\
\text { parameter }\end{array} \\
\AA \\
(\mathbf{a}=\mathbf{b}=\mathbf{c})\end{array}$ & $\begin{array}{c}\text { SSA } \\
\left(\mathrm{m}^{2} / \mathbf{g}\right) \\
(\mathbf{S})\end{array}$ & 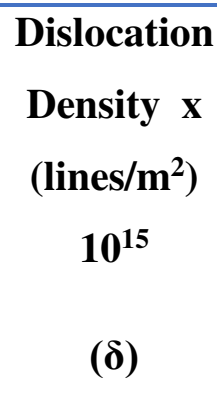 & $\begin{array}{c}\text { Strain } \\
(\varepsilon)\end{array}$ & $\begin{array}{c}\text { Bandgap } \\
\text { in } \mathrm{eV}\end{array}$ \\
\hline pH 7 & 13 & 10.6020 & 92.12 & 8.978 & 0.0085 & 3.42 \\
\hline pH 8 & 14 & 10.6289 & 91.12 & 7.842 & 0.0035 & 4.15 \\
\hline pH 9 & 16 & 10.6146 & 74 & 6.566 & 0.0016 & 4.17 \\
\hline
\end{tabular}

\subsection{W-H analysis}

Williamson-Hall method (W-H) can be applied to compute the microstrain of the fabricated $\mathrm{Y}_{2} \mathrm{O}_{3}$ nanoparticles. The strain was computed from the horizontal line intercept at the $\mathrm{Y}$-axis, it has a non-zero slope (Fig. 2). From the W-H plot, it is noticed that the strain values are very little and therefore their effect on the broadening of peaks is insignificant [21, 22]. However, there is a minor deviation in the particle size for different $\mathrm{pH}$ synthesized samples, due to the presence of strain is account obtained.
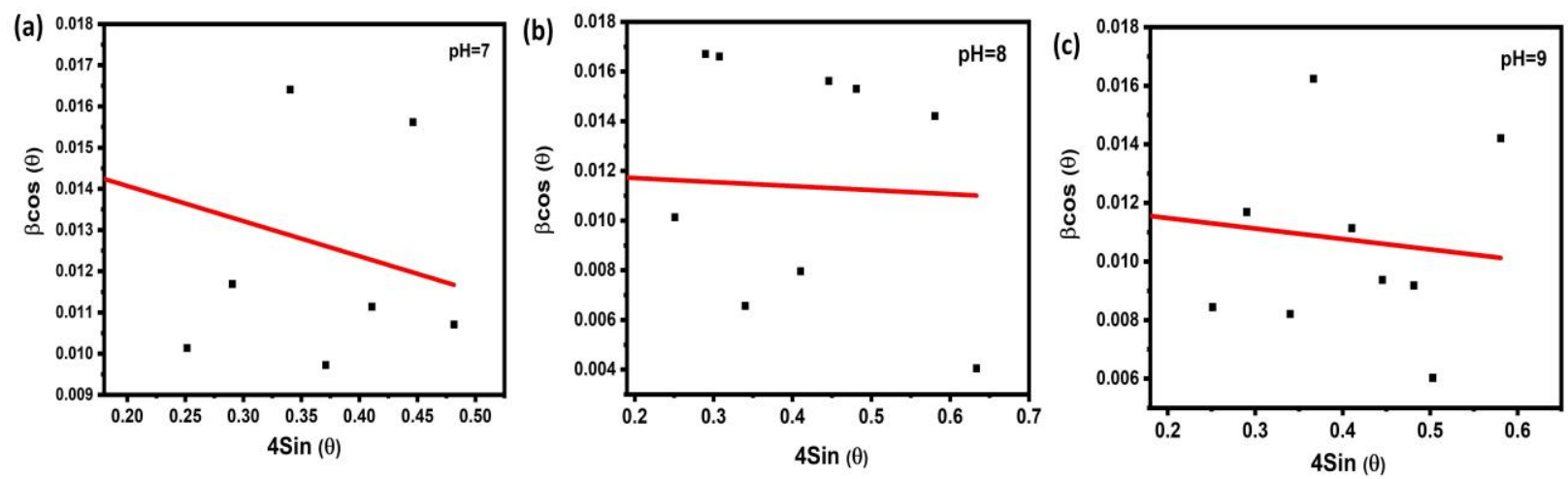

Fig.2. W-H plot for $\mathrm{Y}_{2} \mathrm{O}_{3}$ nanoparticles synthesized with a different $\mathrm{pH}$ value (a) 7 (b) 8 and (c) 9 


\subsection{Morphological Analysis}

SEM micrographs of the fabricated $\mathrm{Y}_{2} \mathrm{O}_{3}$ nanoparticles with a different $\mathrm{pH}$ value are exhibited in Fig. 3 (a-c). The sample synthesized by the solution of $\mathrm{pH}=7$ appeared agglomerated with a spherical nanostructure (Fig. 3a). For $\mathrm{pH}=8$, the $\mathrm{Y}_{2} \mathrm{O}_{3}$ sample exhibited cube like morphology but it shows a much thinner surface (Fig. 3b). Alternatively, From the SEM image of $\mathrm{Y}_{2} \mathrm{O}_{3}$ nanoparticles found from the solution of $\mathrm{pH}=9$, the surface morphology different from other samples was detected. The rod-like morphology was observed for the sample synthesized from $\mathrm{pH}=9$ (Fig. 3c). Fig. 3c shows rods like morphology and their average length: $5.75 \mu \mathrm{m}$, diameter: $120-450 \mathrm{~nm}$. This designates that $\mathrm{pH}$ value is a substantial parameter in adjusting the morphology of $\mathrm{Y}_{2} \mathrm{O}_{3}$ sample. It is evident from fig. 3 that the increase in $\mathrm{pH}$ affected the Yttrium oxide particles owing to the attendance of $\mathrm{OH}^{-}$ions.

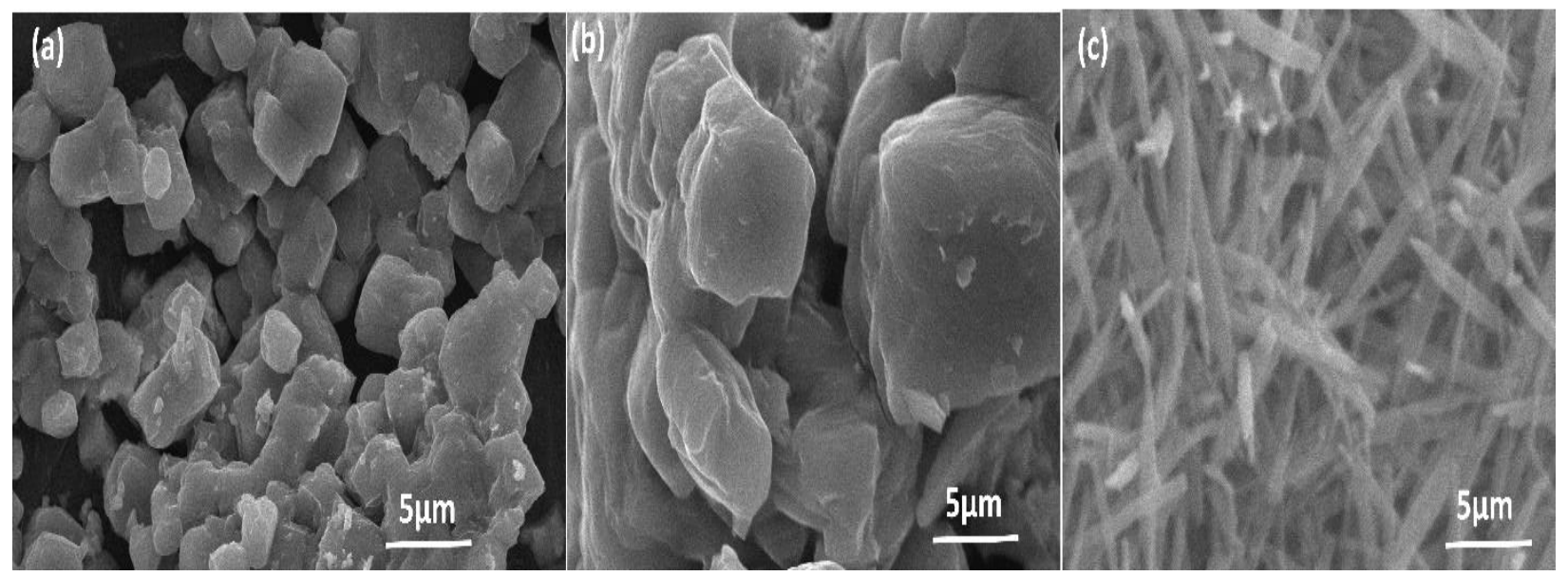

Fig.3. SEM micrographs of $\mathrm{Y}_{2} \mathrm{O}_{3}$ sample with a diverse $\mathrm{pH}$ value (a) $\mathrm{pH}=7$, (b) $\mathrm{pH}=8$ and (c) $\mathrm{pH}=9$

\subsection{FTIR studies}

The FTIR spectra for the $\mathrm{Y}_{2} \mathrm{O}_{3}$ samples fabricated with a diverse $\mathrm{pH}$ value are depicted in Fig. 4. The peak monitored at $3451 \mathrm{~cm}^{-1}$ is because of the stretching vibration of the water molecule [23]. The vibrational peak found at $1633 \mathrm{~cm}^{-1}$ was ascribed to the $\mathrm{OH}$ vibration. The peak observed at $589 \mathrm{~cm}^{-1}$ suggests the stretching vibration of $\mathrm{Y}-\mathrm{O}$, which reveals the presence of yttrium oxide in the crystalline phase. It was obvious that the Y-O absorption bands become broader as the particle size diminishes. There were no additional peaks observed in the spectra, 
indicating its high phase purity of the sample. Although, the slight change in the wavenumber of the samples fabricated at variant $\mathrm{pH}$ values (see Fig.4). This is well matched with the result of the XRD studies.

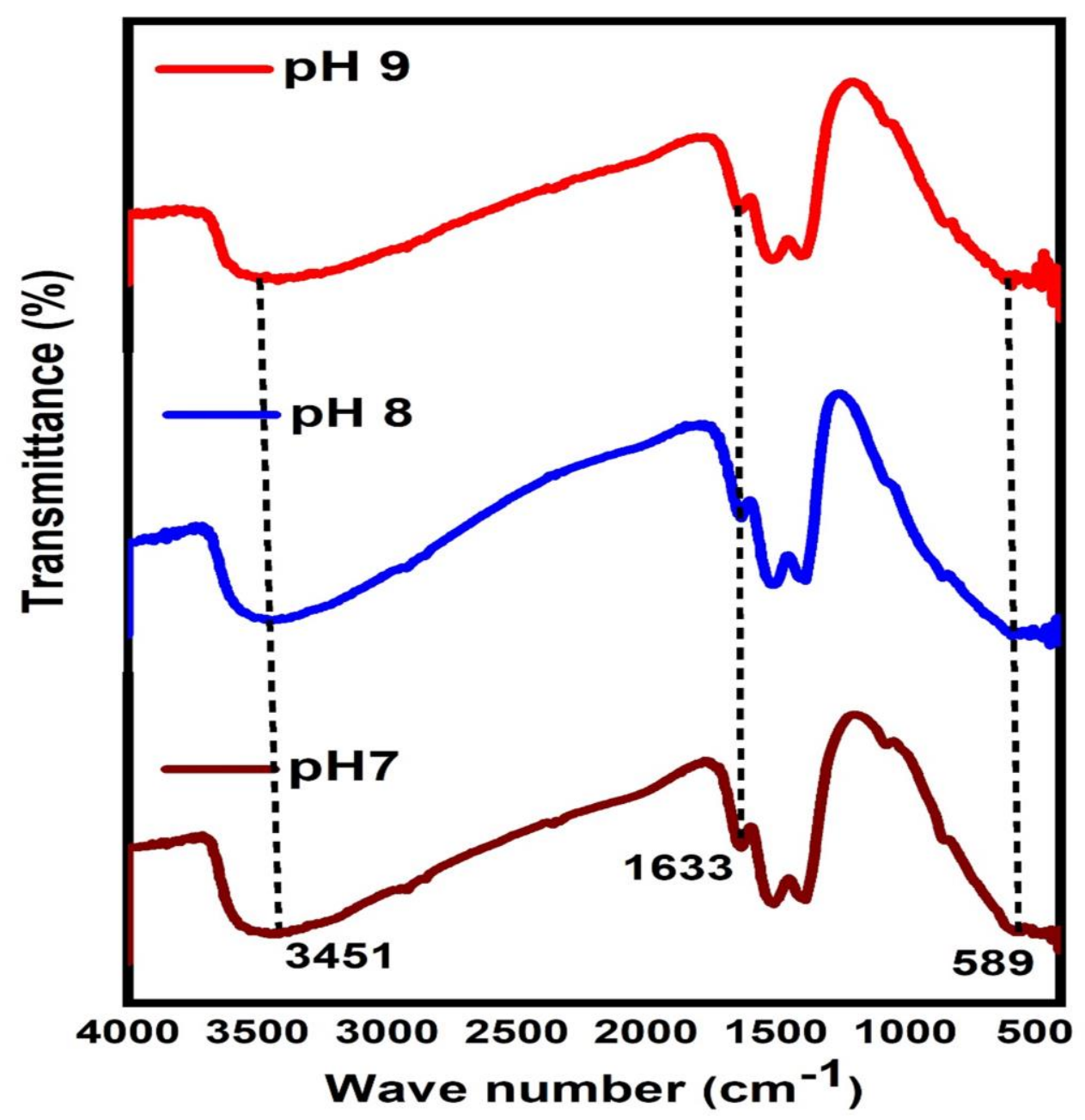

Fig.4. FTIR spectra of $\mathrm{Y}_{2} \mathrm{O}_{3}$ nanoparticles with a different $\mathrm{pH}$ value of 7, 8 and 9

\subsection{UV-DRS spectra}

The UV-Vis absorbance spectra of $\mathrm{Y}_{2} \mathrm{O}_{3}$ nanoparticles fabricated with a diverse $\mathrm{pH}$ values are displayed in Fig. 5. They exhibit strong absorbance band at around $270 \mathrm{~nm}$; it could be connected to the photoexcitation of electrons from the valance band to conduction band [24]. 

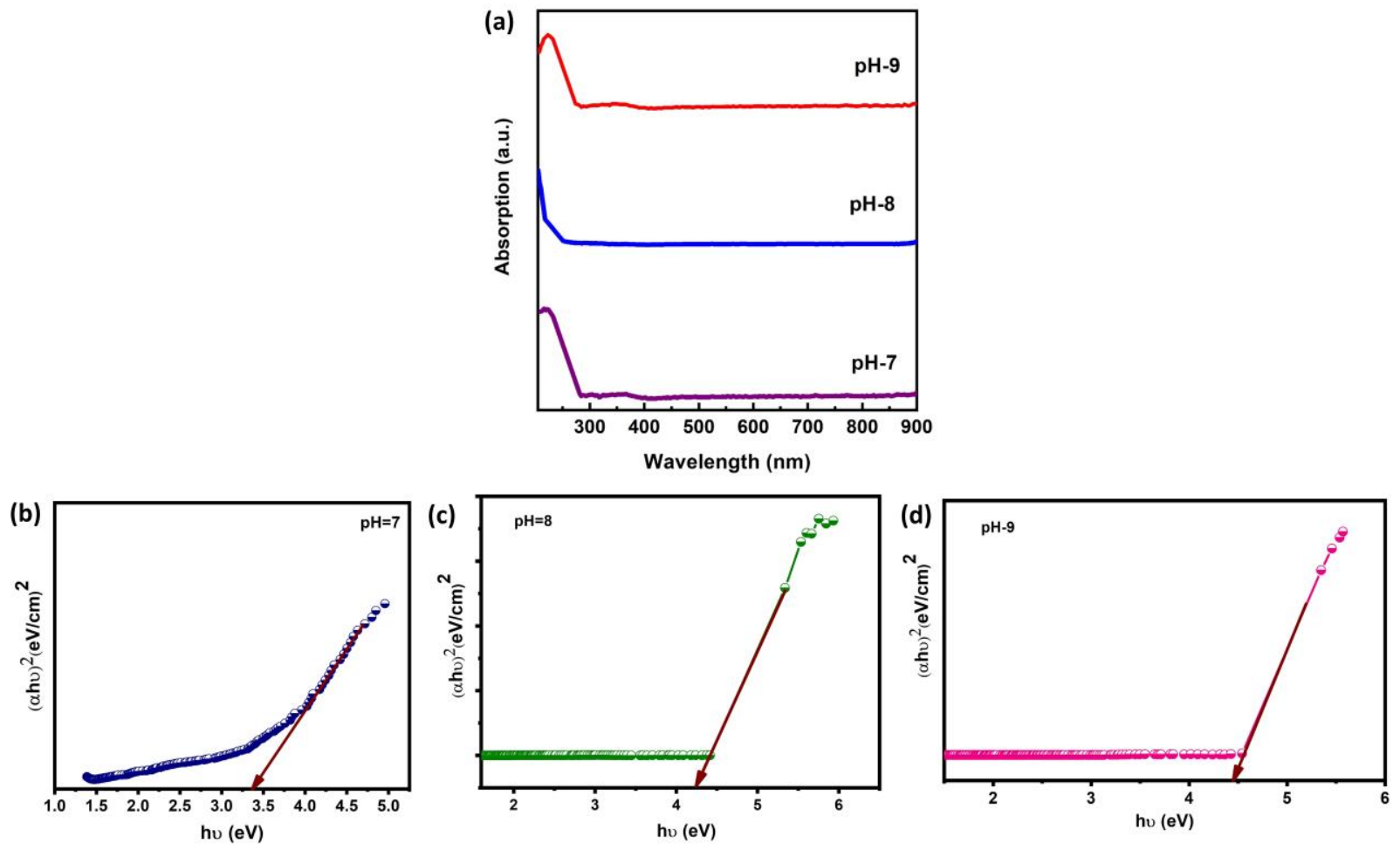

Fig. 5. (a) UV-Vis absorption spectra of $\mathrm{Y}_{2} \mathrm{O}_{3}$ sample and (b-d) bandgap determination of the $\mathrm{Y}_{2} \mathrm{O}_{3}$ nanoparticles prepared at different $\mathrm{pH} 7,8$ and 9

The optical bandgap $\left(\mathrm{E}_{\mathrm{g}}\right)$ of $\mathrm{Y}_{2} \mathrm{O}_{3}$ samples was estimated by using Tauc's plot relation. The absorption coefficient is given by equation (4):

$$
\alpha(h v)=A\left(h v-E_{g}\right)^{n}
$$

Where ' $\mathrm{h} v$ ' is photon energy, ' $\alpha$ 'is absorption coefficient, ' $\mathrm{Eg}$ ' is bandgap energy, and ' $\mathrm{A}$ ' is the constant related to the material. The exponent $n=1 / 2,2,3 / 2$, and 3 corresponds to the allowed direct and indirect, forbidden direct and forbidden indirect transitions, individually [25, 26]. The bandgap was analyzed from a plot of $(\alpha h v)^{2} v s \mathrm{~h} v$. The bandgap was found to be 3.42, 4.15, 4.47 $\mathrm{eV}$ for the $\mathrm{Y}_{2} \mathrm{O}_{3}$ nanoparticles prepared at $\mathrm{pH}=7,8$, and 9 respectively. It has been observed that the bandgap energy reveals a blue move in the absorption edge for the samples with enhancing of $\mathrm{pH}$ due to their changing morphologies and surface microstructures [27]. 


\subsection{Photoluminescence analysis}

Figure 6 shows the room temperature photoluminescence spectra of $\mathrm{Y}_{2} \mathrm{O}_{3}$ samples fabricated at various $\mathrm{pH}$ values in the emission wavelength range of $270-450 \mathrm{~nm}$. The emission spectra traced under the excitation wavelength range of $250 \mathrm{~nm}$. The $\mathrm{Y}_{2} \mathrm{O}_{3}$ samples exhibit two emission peaks near band edge (NBE) UV emission and deep level (DL) defects associated with the visible region. The strong UV (NBE) emission at 340-390 nm results from the electron-hole recombination $[28,29]$. The $\mathrm{Y}_{2} \mathrm{O}_{3}$ sample exhibit strong violet emission peak at $420 \mathrm{~nm}$ and it is characteristic to the recombination of electrons intensely trapped in oxygen vacancies with photogenerated holes [30]. The intensity of the NBE emission peak depends on the morphology of the product and crystallite size. In this case, the surface morphology of the sample distinct from other samples was observed from SEM, which is in favour of increased intensity in the NBE emission. However, the visible emission is communicated to the oxygen vacancy and interstitial defects within the bandgap of $\mathrm{Y}_{2} \mathrm{O}_{3}$ nanostructures. The high intensity visible emission shows that the higher $\mathrm{pH}$ values needed for high luminescence efficiency. Furthest, this can be accomplished that the $\mathrm{pH}$ values play a key function not only in improving the surface morphology of $\mathrm{Y}_{2} \mathrm{O}_{3}$ nanostructures but also in changing and improving the optical studies of $\mathrm{Y}_{2} \mathrm{O}_{3}$ nanostructure. The photocatalytic activity of metal oxide nanomaterials surmises the crystallite size, diverse morphologies, and surface defects. In our study, the higher surface defects demonstrated a high impact on the toxic dye degradation. 


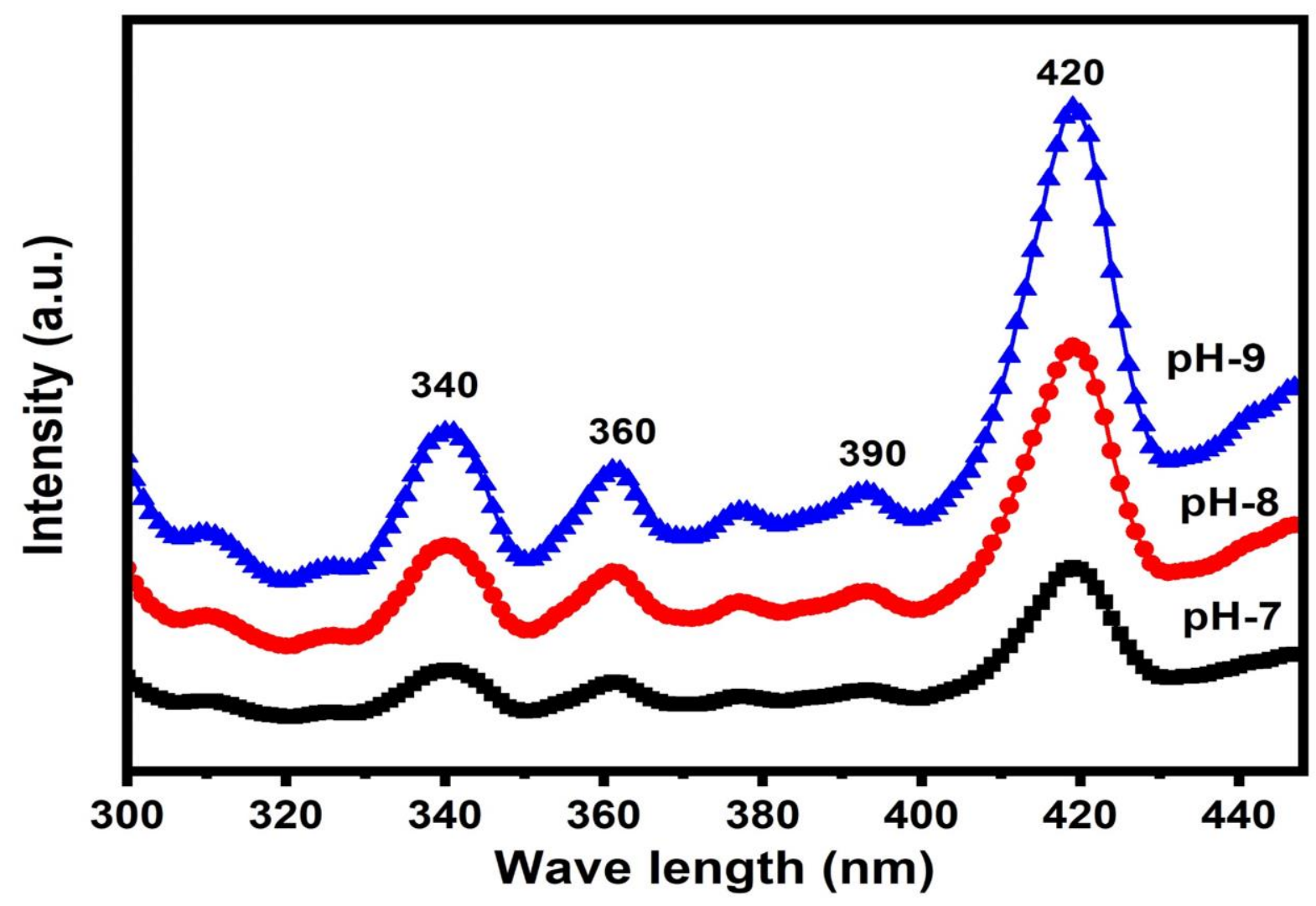

Fig.6. Photoluminescence spectra of $\mathrm{Y}_{2} \mathrm{O}_{3}$ samples prepared at diverse $\mathrm{pH}=7,8$ and 9

\subsection{Photocatalytic activity}

The photocatalytic absorbance spectrum of $\mathrm{Y}_{2} \mathrm{O}_{3}$ sample $(\mathrm{pH}=9)$ beneath sunlight presented in Fig. 7. In the occurrence of $\mathrm{Y}_{2} \mathrm{O}_{3}$, the absorbance of the dye (MB) solution decreased with a go up in the irradiation time. From Fig. 8, the characteristic absorption of MB at $662 \mathrm{~nm}$ decreased swiftly with the raise in exposure time. This designates that the dye concentration in the solution decreased quickly and virtually vanished in 150 mins. The percentage of degradation was equal to 95 in 150 mins [30-32]. The photocatalytic MB dye degradation follows pseudo-first-order kinetics. It follows from the kinetics study that $\mathrm{Y}_{2} \mathrm{O}_{3}(\mathrm{pH}=9)$ displays a superior photocatalytic activity with a kinetic constant (k) equal to $2.510 \times 10^{-3} \mathrm{~min}^{-1}$.

The recombination of the electron-hole pairs at the surface defect site, and react with the adsorbed $\mathrm{O}_{2}$ molecule to form superoxide anion $\mathrm{O}^{2-}$ radical, while the hole reacts with the $\mathrm{OH}^{-}$ surface group to form $\cdot \mathrm{OH}$ radicals which can react effectively decompose the dye molecules 
into carbon dioxide and water. The main reasons for the enhanced photocatalysis of $\mathrm{Y}_{2} \mathrm{O}_{3}(\mathrm{pH}=9)$ is due to the partition of charge carriers, the reduction of the bandgap, and the rod-like (1-D) structure $[33,34]$.

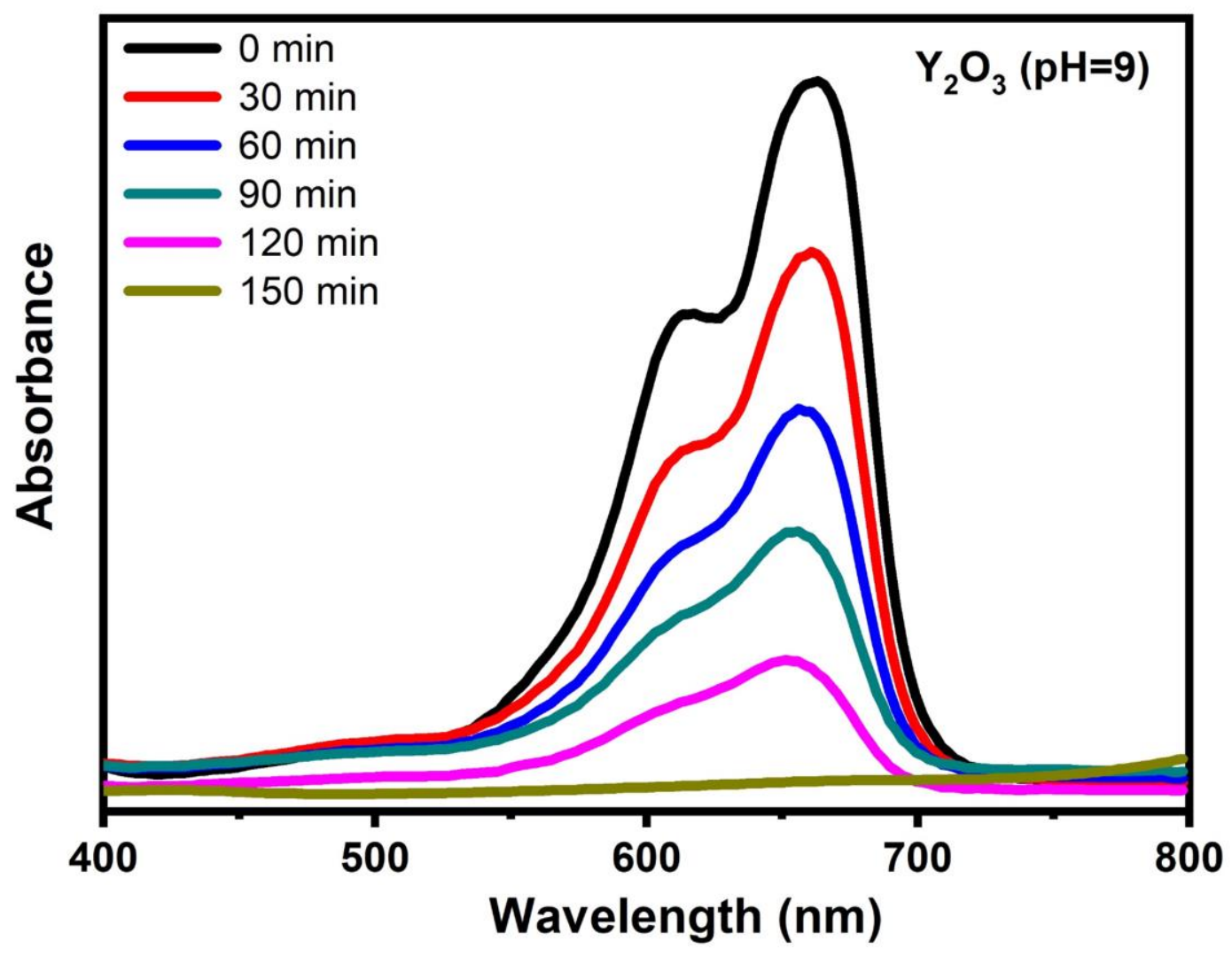

Fig.7 Absorbance spectrum of $\mathrm{MB}$ with $\mathrm{Y}_{2} \mathrm{O}_{3}(\mathrm{pH}=9)$ sample under nature solar light irradiation

\subsection{Antibacterial activity}

The antibacterial studies of $\mathrm{Y}_{2} \mathrm{O}_{3}(\mathrm{pH}=9)$ were assessed adjacent to Staphylococcus aureus and Salmonella typhi bacterial strains and were checked at diverse concentrations (50 and 100 $\mu \mathrm{g} / \mathrm{mL}$ ). $\mathrm{Y}_{2} \mathrm{O}_{3}$ nanorods demonstrated good antibacterial action against Staphylococcus aureus $(20 \mathrm{~mm}$ ) at $100 \mu \mathrm{g} / \mathrm{mL}$. Table 2 recapitulates the zone of inhibition (ZOI) values acquired adjacent to both tested microbes.

The antibacterial mechanism of the fabricated $\mathrm{Y}_{2} \mathrm{O}_{3}$ can be elucidated by [35- 37]

I. Production of reactive oxygen species (ROS) 


\section{Release of heavy metal ions}

The production of ROS on the surface of prepared nanomaterials has accounted by Karthik et al. [38]. $\mathrm{Y}_{2} \mathrm{O}_{3}$ nanorods have created $\mathrm{ROS}$ via the Fenton reaction (FR) directing to lipid peroxidation, injure of DNA, and decay of protein possibly obliterate bacteria without detrimental normal cells. The ROS (from $\mathrm{Y}_{2} \mathrm{O}_{3}$ nanorods) manipulated the oxidative stress in the intracellular functional alterations (bacteria cell wall connect with the mesosome) and foremost to the cell bereavement.

Typically, the antibacterial action chiefly varies upon the specific surface area, crystallite size, and diverse morphologies. $\mathrm{Y}_{2} \mathrm{O}_{3}$ nanoparticles provide $\mathrm{ROS}$ via the FR as follows:

$$
\begin{aligned}
& \text { i. } \mathrm{Y}_{2} \mathrm{O}_{3}+\mathrm{hv} \rightarrow \mathrm{e}^{-}+\mathrm{h}^{+} \\
& \text {ii. } \mathrm{h}^{+}+\mathrm{H}_{2} \mathrm{O} \rightarrow \cdot \mathrm{OH}+\mathrm{H}^{+} \\
& \text {iii. } \mathrm{e}^{-}+\mathrm{O}_{2} \rightarrow \mathrm{O}_{2}^{-} \\
& \text {iv. } \mathrm{O}_{2}^{-}+\mathrm{H}^{+} \rightarrow \mathrm{HO}_{2} \cdot \\
& \text { v. } \mathrm{HO}_{2}+\mathrm{H}^{+}+\mathrm{e}^{-} \rightarrow \mathrm{H}_{2} \mathrm{O}_{2}
\end{aligned}
$$

Maria Magdalane et al. have stated the $\mathrm{Y}^{3+}$ from the $\mathrm{Y}_{2} \mathrm{O}_{3}$ nanoparticles [1]. Based on the Maria Magdalane et al. report, the discharged $\mathrm{Y}^{3+}$ from the $\mathrm{Y}_{2} \mathrm{O}_{3}$ nanorods take action as positive and

\begin{tabular}{|c|c|c|c|c|c|}
\hline \multirow{3}{*}{$\begin{array}{c}\text { Tested } \\
\text { microorganisms }\end{array}$} & \multirow{3}{*}{$\begin{array}{l}\text { Gram- } \\
\text { reaction }\end{array}$} & \multicolumn{2}{|c|}{$\mathrm{ZOI}(\mathrm{mm})$} & \multirow{3}{*}{$\begin{array}{c}\text { Positive } \\
\text { control } \\
\text { (Streptomycin) }\end{array}$} & \multirow{3}{*}{$\begin{array}{c}\text { Negative } \\
\text { control }\end{array}$} \\
\hline & & $50 \mu \mathrm{g} / \mathrm{mL}$ & 100 & & \\
\hline & & & $\mu \mathrm{g} / \mathrm{mL}$ & & \\
\hline S. aureus & $+\mathrm{ve}$ & 16 & 20 & 28 & -- \\
\hline S. typhi & -ve & 14 & 18 & 22 & -- \\
\hline
\end{tabular}
the cell wall takes action as a negative charge, they are evenly engrossed. Such communication can guide to decay of proteins, failure of DNA reproduction capability, and subsequently, the bereavement of the bacterium [39-41].

Table 2. The ZOI values of the prepared $\mathrm{Y}_{2} \mathrm{O}_{3}(\mathrm{pH}=9)$ by co-precipitation method 


\section{Conclusion}

The yttrium oxide nanomaterials were effectively fabricated by the co-precipitation route and their structural, surface morphology, optical, photocatalytic, and antibacterial properties were deliberated. XRD pattern confirms the cubic structure of $\mathrm{Y}_{2} \mathrm{O}_{3}$. The lower $\mathrm{pH}$ values give a less crystallite size and lattice constant compared with the higher $\mathrm{pH}$ values. The $\mathrm{pH}$ value plays an important role in obtaining $\mathrm{Y}_{2} \mathrm{O}_{3}$ samples with various morphologies. SEM images show the different morphologies like agglomeration of spherical nanoparticles, cube like and nanorods morphology. The $\mathrm{Y}_{2} \mathrm{O}_{3}$ samples exhibit two emission peaks NBE UV emission and visible region. The PL intensity of these emissions altered with the morphology of $\mathrm{Y}_{2} \mathrm{O}_{3}$ nanostructure obtained at different $\mathrm{pH}$ values. The $\mathrm{Y}_{2} \mathrm{O}_{3}$ sample synthesized at $\mathrm{pH}$ value 9 possess strong blue emission, nanorods like morphology and good crystallinity can be considered as potential luminescent material for optoelectronic application. $\mathrm{Y}_{2} \mathrm{O}_{3}(\mathrm{pH}=9)$ sample illustrated substantial photocatalytic (adjacent to $\mathrm{MB}$ ) and antibacterial (against foodborne pathogens) activity. $\mathrm{Y}_{2} \mathrm{O}_{3}$ $(\mathrm{pH}=9)$ sample proves to be an appropriate material for wastewater remediation and biomedical applications.

\section{References}

1. C. Maria Magdalane, K. Kaviyarasu, J. Judith Vijaya, B. Siddhardha, B. Jeyaraj, Facile synthesis of heterostructured cerium oxide/yttrium oxide nanocomposite in UV light induced photocatalytic degradation and catalytic reduction: Synergistic effect of antimicrobial studies, J. Photochem. Photobiol B Biol. 173 (2017) 23-34.

2. A. Mobeen Amanulla, SK. Jasmine Shahina, R. Sundaram, C. Maria Magdalane, K. Kaviyarasu, Douglas Letsholathebe, S.B. Mohamed, J. Kennedy, M. Maaza, Antibacterial, magnetic, optical and humidity sensor studies of $\beta-\mathrm{CoMoO}_{4}-\mathrm{Co}_{3} \mathrm{O}_{4}$ nanocomposites and its synthesis and characterization, J. Photochem. Photobiol B Biol. 183 (2018) 233-241.

3. C. Maria Magdalane, K. Kaviyarasu, G. Maria Assuntha Priyadharsini, A.K.H. Bashir, N. Mayedwa, N. Matinise, Abdulgalim B. Isaev, Naif Abdullah Al-Dhabi, Mariadhas Valan Arasu, S. Arokiyaraj, J. Kennedy, M. Maaza, Improved photocatalytic decomposition of aqueous Rhodamine-B by solar light illuminated hierarchical yttria nanosphere decorated ceria nanorods, J. Mater. Res. Technol. 8 (3) (2019) 2898-2909. 
4. C. Maria Magdalane, K. Kaviyarasu, N. Matinise, N. Mayedwa, N. Mongwaketsi, Douglas Letsholathebe, G.T. Mola, Naif AbdullahAl-Dhabi, Mariadhas Valan Arasu, M. Henini, J. Kennedy, M. Maaza, B. Jeyaraj, Evaluation on La2O3 garlanded ceria heterostructured binary metal oxide nanoplates for UV/ visible light induced removal of organic dye from urban wastewater, S. Afr. Chem. Eng. 26 (2018) 49-60.

5. K. Kaviyarasu, C. Maria Magdalane, D. Jayakumar, Y. Samson, A.K.H. Bashir, M. Maaza, Douglas Letsholathebe, Ahmed Hossam Mahmoud, J. Kennedy, High performance of pyrochlore like $\mathrm{Sm}_{2} \mathrm{Ti}_{2} \mathrm{O}_{7}$ heterojunction photocatalyst for efficient degradation of Rhodamine-B dye with waste water under visible light irradiation, J. King Saud. Univ. Sci. 32 (2) (2020) 1516-1522.

6. S. Panimalar, R. Uthrakumar, E.Tamil Selvi, P. Gomathy, C. Inmozhi, K. Kaviyarasu, J. Kennedy, Studies of MnO2/g-C3N4 hetrostructure efficient of visible light photocatalyst for pollutants degradation by sol-gel technique, Surf. Interfaces 20 (2020) 100512.

7. T. Yamaguchi, N. Ikeda, H. Hattori and K. Tanable, Surface and catalytic properties of cerium oxide, J. Catal. 67 (1981) 324-330.

8. G. Blasse, B. C. Grabmair, A general introduction to luminescece materials, Luminescent Materials, Springer-verlag, Berlin,1994.

9. C. Feldmann, T. Justel, C. R. Ronda, P. Schmidt, Inorganic Luminescent Materials: 100 Years of Research and Application, J. Adv. Funct. Mater 13 (2003) 511-516.

10. S. Nie, S. R. Emory, Probing Single Molecules and Single Nanoparticles by SurfaceEnhanced Raman Scattering, Science 275 (1997) 1102-1106.

11. A. Sathiya Priya, D. Geetha, K. Karthik, M. Rajamoorthy, Investigations on the enhanced photocatalytic activity of (Ag, La) substituted nickel cobaltite spinels, Solid State Sci. 98 (2019) 105992.

12. T. Hirai, Y. Asada and I. Komasawa, Preparation of $\mathrm{ZnO}$ nanoparticles in a reverse micellar system and their photoluminescence properties, J. Colloid Interface Sci. 284, (2005) 184-189. 
13. L. Lin, S.A. Starostin, S. Li, S.A. Khan, V. Hessel, Synthesis of yttrium oxide nanoparticles via a facile microplasma-assisted process, Chem. Eng. Sci. 178 (2018) 157166.

14. O. Singh, M. Palsingh, N. Kohli and R. Chand singh, Effect of $\mathrm{pH}$ on the morphology and gas sensing properties of $\mathrm{ZnO}$ nanostructures, Sens. Actuators B Chem. 166-167 (2012) $438-443$.

15. J. Dhanaraj, R. Jagannathan, T. R.N. Kutty, C. H. Lu, Photoluminescence Characteristics of $\mathrm{Y}_{2} \mathrm{O}_{3}: \mathrm{Eu}^{3+}$ Nanophosphors Prepared Using Sol-Gel Thermolysis. J. Phys.Chem.B 105 (2001) 11098-11105.

16. H. Tomaszewski, h. Weglarz, R. D. Gryse, Crystallization of yttria under hydrothermal conditions, J. Eur. Ceram. Soc.17 (1997) 403-406.

17. T. Ye, Z. Guiwen, Z. Weiping, X. Shangda, Combustion synthesis and photoluminescence of nanocrystalline $\mathrm{Y}_{2} \mathrm{O}_{3}$ :Eu phosphors, Mater. Res. Bull.32 (1997) 501-506.

18. A. P. Jadhav, A. Pawar, C. W. kim, H. G. Cha, U. pal, Y. S. Kang, Effect of Different Additives on the Size Control and Emission Properties of $\mathrm{Y}_{2} \mathrm{O}_{3}: \mathrm{Eu}^{3+}$ Nanoparticles Prepared through the Coprecipitation Method, J. Phys. Chem. C113 (2009) 16652-16657.

19. P. Scherrer, Bestimmung der Grosse und der inneren Struktur von Kolloidteilchen Mittels Rontgenstrahlen, Nachrichten von der Gesellschaft der Wissenschaften, Gottingen. MathPhys Kl 2 (1918) 98-100.

20. J. Chen, L. Yaling, Y. Wang, J. Yun, D. Cao, Preparation and characterization of zinc sulfide nanoparticles under high-gravity environment, Mat. Res. Bull. 39(2) (2004) 185194.

21. S. Lakshmanaperumal, P. Hemalatha, M. Alagar, K. N. Pandiyaraj, Investigation of Structural, Optical and Photocatalytic Properties of Sr Doped ZnO Nanoparticles, Int. J. Chem. Phys. Sci. 4 (2015) 1-13. 
22. P. Hemalatha, S.N. Karthick, K.V. Hemalatha, M. Yi, Hee-Je Kim, M. Alagar, La-doped $\mathrm{ZnO}$ nanoflower as photocatalyst for methylene blue dye degradation under UV irradiation. J. Mater. Sci. Mater. Electron. 27 (2016) 2367-2378.

23. M. Kottaisamy, D. Jeyakumar, R. Jegnnathan, M. M. Rao, Yttrium oxide: $\mathrm{Eu}^{3+}$ red phosphor by self-propagating high temperature synthesis, Mater.Res. Bull. 31 (1996) 1013-1020.

24. R. Murugesan, S. Sivakumar, K. Karthik, P. Anandan, M. Haris, Structural, optical and magnetic behaviors of Fe/Mn-doped and co-doped CdS thin films prepared by spray pyrolysis method, Appl. Phys. A, 125 (2019) 281.

25. J. I. Pankove, Optical process in semiconductors, Prentice- Hall, New Jersey, 1971.

26. J. Kennedy, P.P. Murmu, J. Leveneur, A. Markwitz, J. Futter, Controlling preferred orientation and electrical conductivity of zinc oxide thin films by post growth annealing treatment, Appl. Surf. Sci. 367 (2016) 52-58.

27. Prakasit Intaphong, Anukorn Phuruangrat, K. Karthik, Phattranit Dumrongrojthanath, Titi pun Thongtem, Somchai Thongtem, Effect of $\mathrm{pH}$ on phase, morphology and photocatalytic properties of $\mathrm{BiOBr}$ synthesized by hydrothermal method, J. Inorg. Organomet. Polym. Mater. 30 (2020) 714-721.

28. V. Rajendran, K. Anandan, Different ionic surfactants assisted solvothermal synthesis of zero-, three and one-dimensional nickel oxide nanostructures and their optical properties, Mater. Sci. Semicond. Process. 38 (2015) 203-208.

29. S. Mohseni Meybodi, S.A. Hosseini, M. Rezaee, S.K. Sadrnezhaad, D. Mohammadyani, Synthesis of wide band gap nanocrystalline $\mathrm{NiO}$ powder via a sonochemical method, Ultrason. Sonochem. 19 (2012) 841-845.

30. K. Karthik, V. Revathi, Tetiana Tatarchuk Microwave-assisted green synthesis of $\mathrm{SnO}_{2}$ nanoparticles and their optical and photocatalytic properties, Mol. Cryst. Liq. Cryst. 671:1 (2018) 17-23. 
31. Parangusan, H., Ponnamma, D., Al-Maadeed, M.A.A. and Marimuthu, A, Nanoflower-like Yttrium-doped ZnO Photocatalyst for the Degradation of Methylene Blue Dye, Photochem. Photobiol. 94 (2018) 237-246.

32. Parangusan, H., Ponnamma, D, Al-Maadeed, M.A.A, Effect of cerium doping on the optical and photocatalytic properties of $\mathrm{ZnO}$ nanoflowers, Bull. Mater. Sci. 42 (2019) 179.

33. N. Benameur, M.A. Chakhoum, A. Boukhachem, M.A. Dahamni, M. Ghamnia, N. Hacini, J.-P. Pireaux, L. Houssiau, A. Ziouche, Investigation of some physical properties of pure and Co-doped $\mathrm{MoO}_{3}$ synthesized on glass substrates by the spray pyrolysis method, Journal of Electron Spectroscopy and Related Phenomena, Volume 234, 2019,Pages 71-79.

34. M.A. Chakhoum, A. Boukhachem, M. Ghamnia, N. Benameur, N. Mahdhi, K. Raouadi, M. Amlouk, An attempt to study (111) oriented NiO-like TCO thin films in terms of structural, optical properties and photocatalytic activities under strontium doping, Spectrochimica Acta Part A: Molecular and Biomolecular Spectroscopy, Volume 205, 2018, Pages 649-660.

35. V. Revathi, K. Karthik, Physico-chemical properties and antibacterial activity of Hexakis (Thiocarbamide) Nickel (II) nitrate single crystal, Chem. Data. Collections 21 (2019) 100229.

36. Jolly Bhadra, Hemalatha Parangusan, Anton Popelka, Marian Lehocky, Petr Humpolicek, Noora Al-Thani, Electrospun Polystyrene/PANI-Ag fibers for organic dye removal and antibacterial application, J. Environ. Chem. Eng. 8 (3) (2020) 103746.

37. R. Aswini, S. Murugesan and K. Kannan, Bio-engineered $\mathrm{TiO}_{2}$ nanoparticles using Ledebouria revoluta extract: Larvicidal, histopathological, antibacterial and anticancer activity, Int. J. Environ. Anal. Chem. (2020) doi:10.1080/ 03067319.2020.1718668. 
38. Karthik Kannan, Devi Radhika, Kishor Kumar Sadasivuni, Kakarla Raghava Reddy, Anjanapura V. Raghu, Nanostructured metal oxides and its hybrids for photocatalytic and biomedical applications, Adv. Colloid Interface Sci. 281 (2020) 102178.

39. Karthik Kannan, Dhanuskodi Sivasubramanian, Prabukumar Seetharaman, Sivaramakrishanan Sivaperuaml, Structural and biological properties with enhanced photocatalytic behaviour of $\mathrm{CdO}-\mathrm{MgO}$ nanocomposite by microwave-assisted method, Optik 204 (2020) 164221.

40. K. Karthik, S. Dhanuskodi, C. Gobinath, S. Prabukumar, S. Sivaramakrishnan, Fabrication of $\mathrm{MgO}$ nanostructures and its efficient photocatalytic, antibacterial and anticancer performance, J. Photochem. Photobiol B Biol. 190 (2019) 8-20.

41. Karthik Kannan, D. Radhika, Maria P. Nikolova, Kishor Kumar Sadasivuni, Namitha R, Structural and functional properties of rare earth-based (NiO-CGO) nanocomposite produced by effective multiple doping approach via co-precipitation, Mater. Technol.

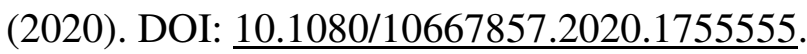


Figures

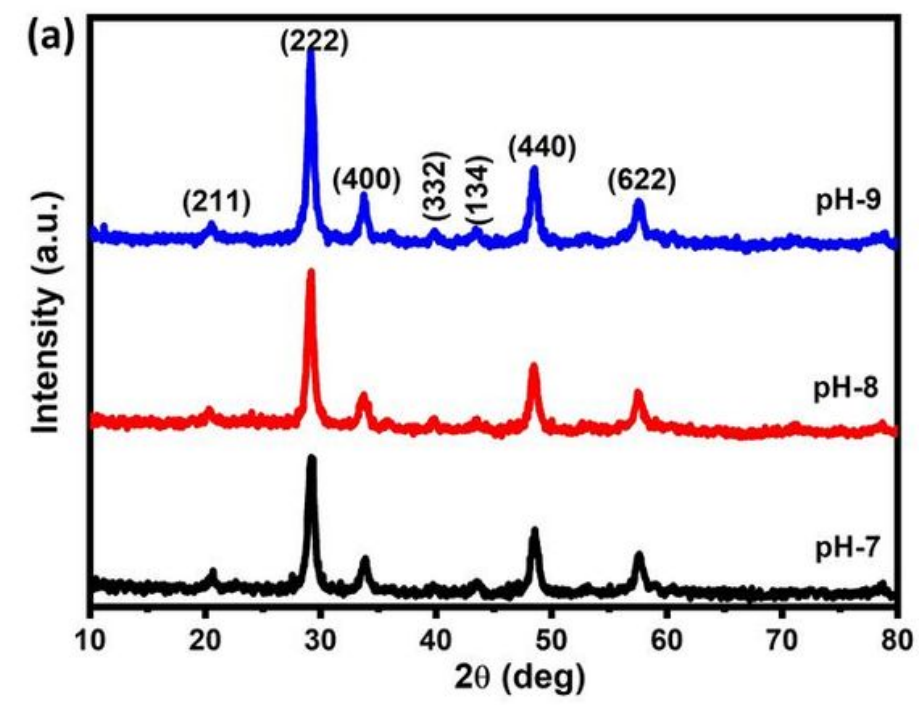

(b)
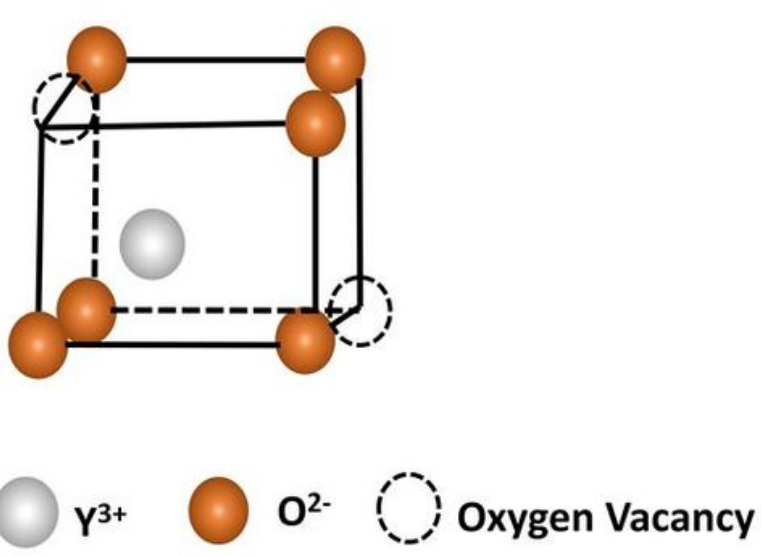

Figure 1

XRD patterns of Y2O3 nanoparticles prepared with different $\mathrm{pH}$ values
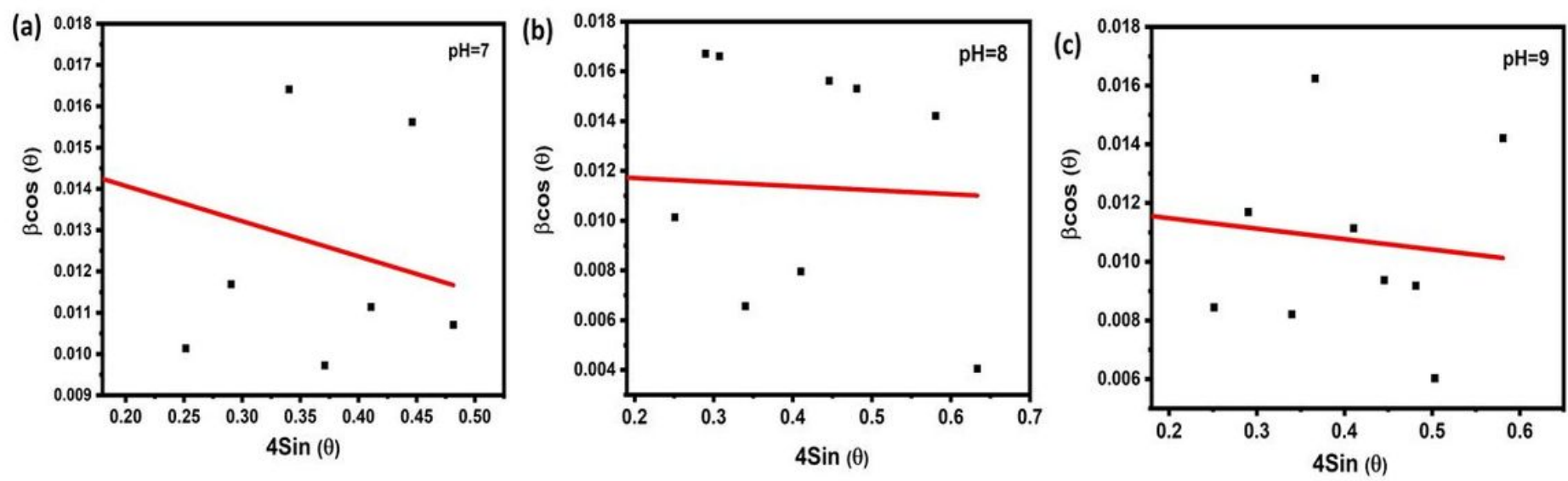

Figure 2

W-H plot for Y2O3 nanoparticles synthesized with a different pH value (a) 7 (b) 8 and (c) 9 


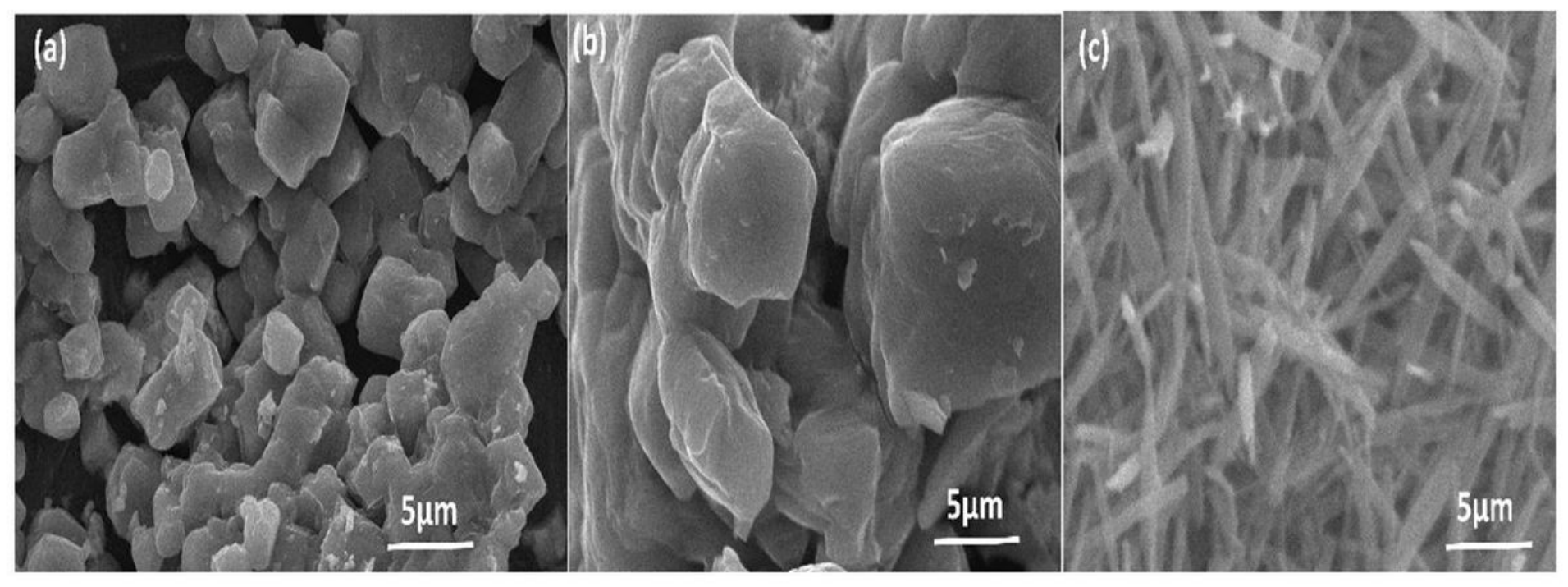

Figure 3

SEM micrographs of $\mathrm{Y} 2 \mathrm{O} 3$ sample with a diverse $\mathrm{pH}$ value (a) $\mathrm{pH}=7$, (b) $\mathrm{pH}=8$ and (c) $\mathrm{pH}=9$ 


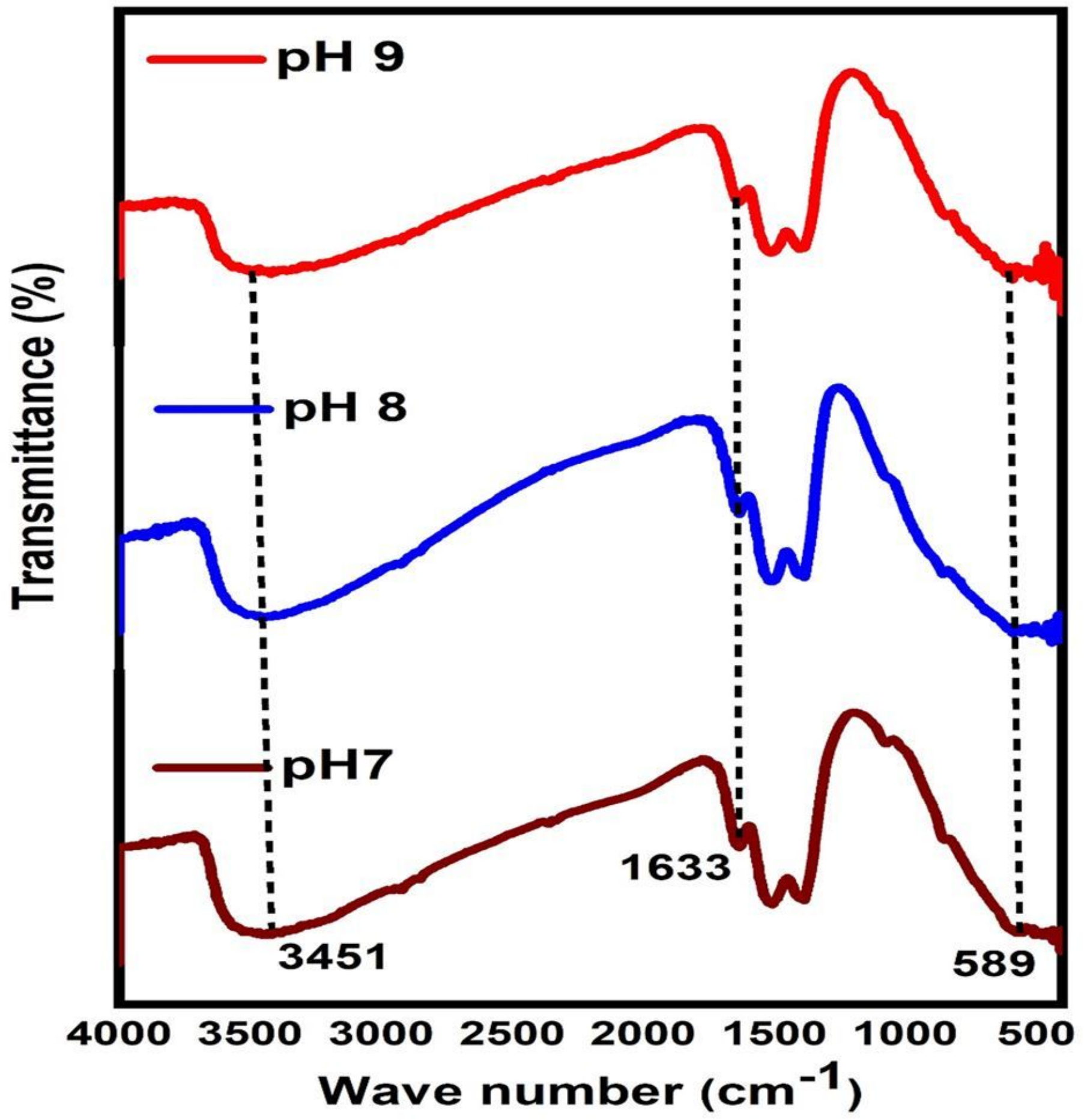

Figure 4

FTIR spectra of Y2O3 nanoparticles with a different $\mathrm{pH}$ value of 7,8 and 9 

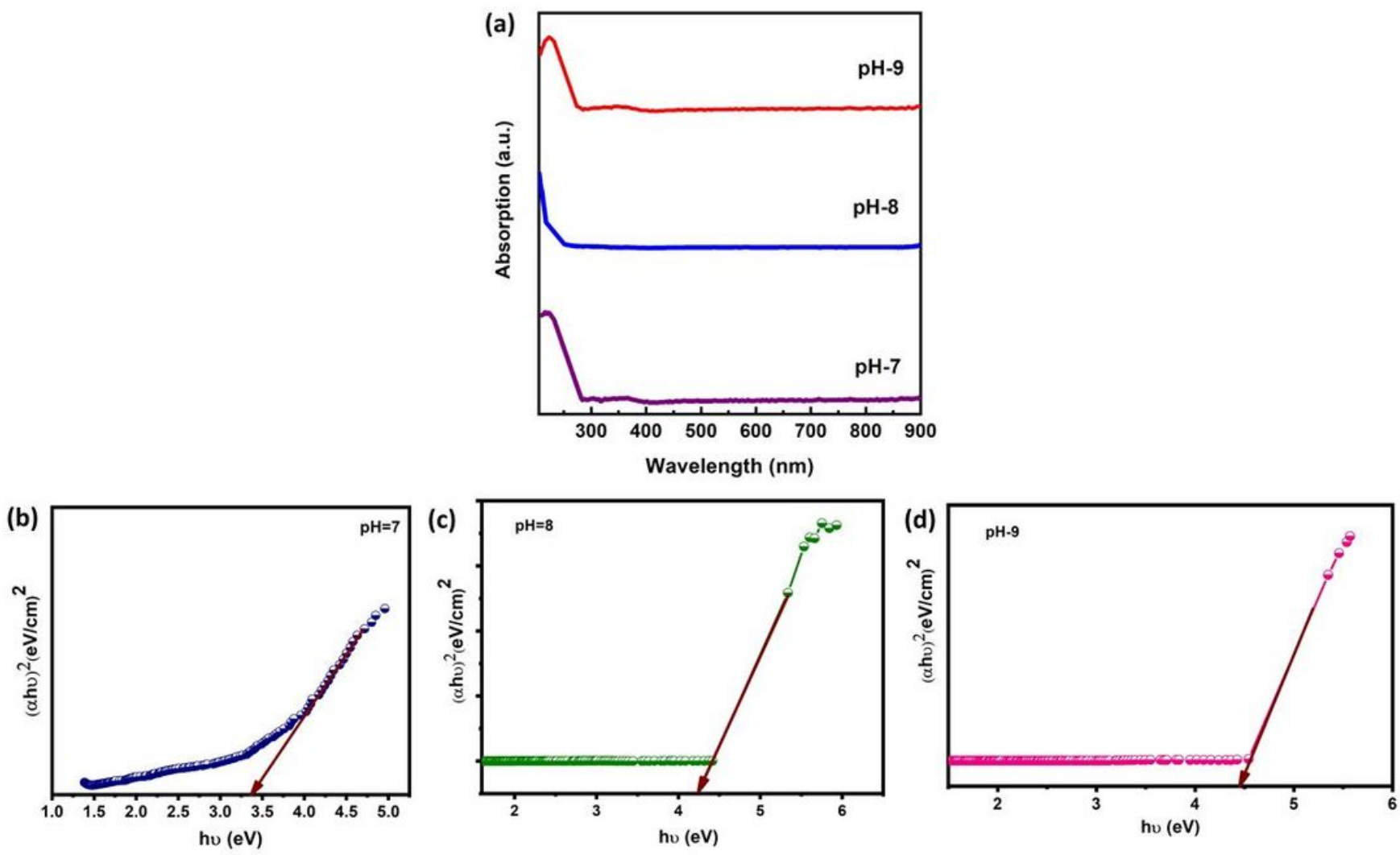

Figure 5

(a) UV-Vis absorption spectra of Y2O3 sample and (b-d) bandgap determination of the Y2O3 nanoparticles prepared at different $\mathrm{pH} 7,8$ and 9 


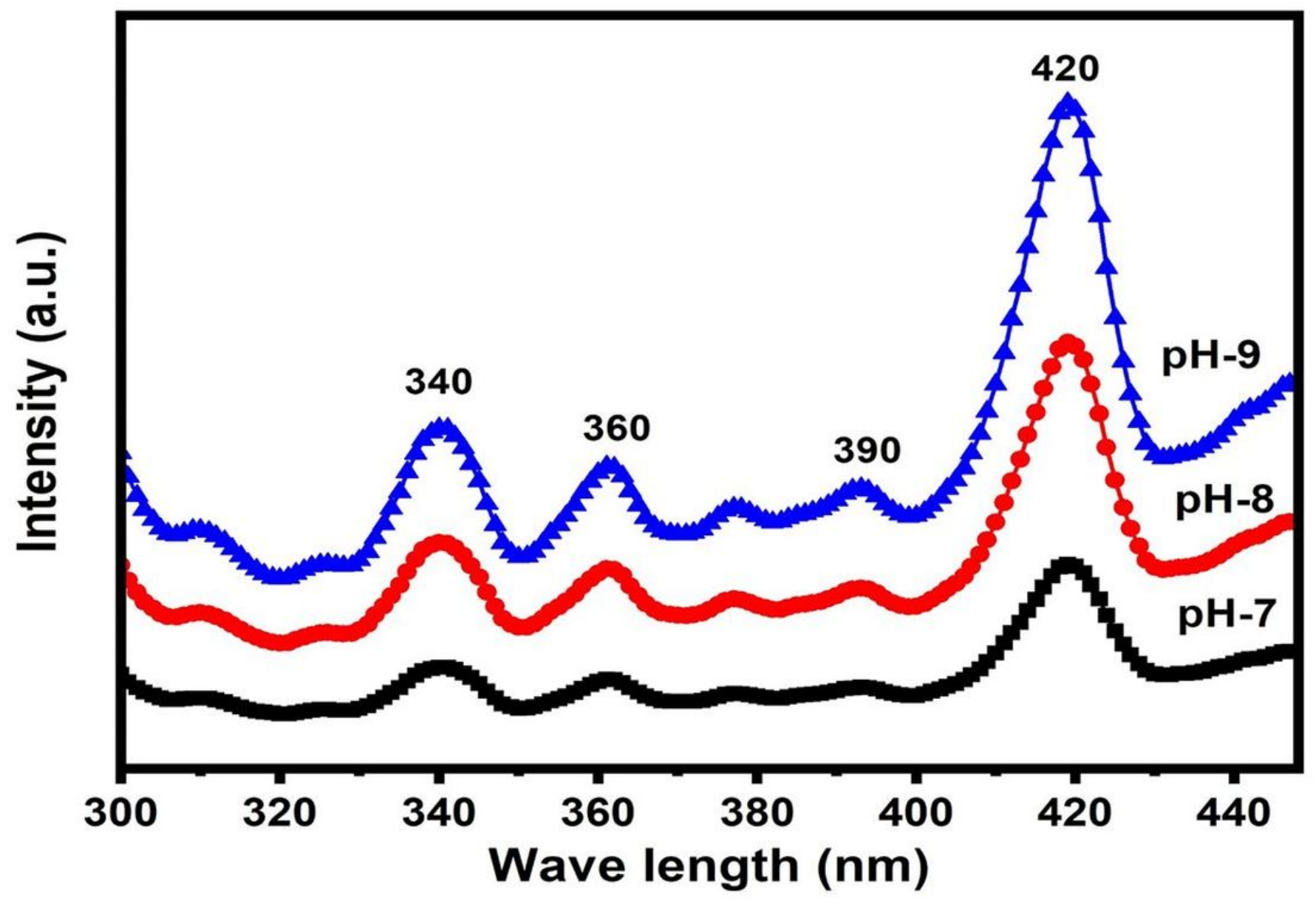

Figure 6

Photoluminescence spectra of $\mathrm{Y} 2 \mathrm{O} 3$ samples prepared at diverse $\mathrm{pH}=7,8$ and 9 


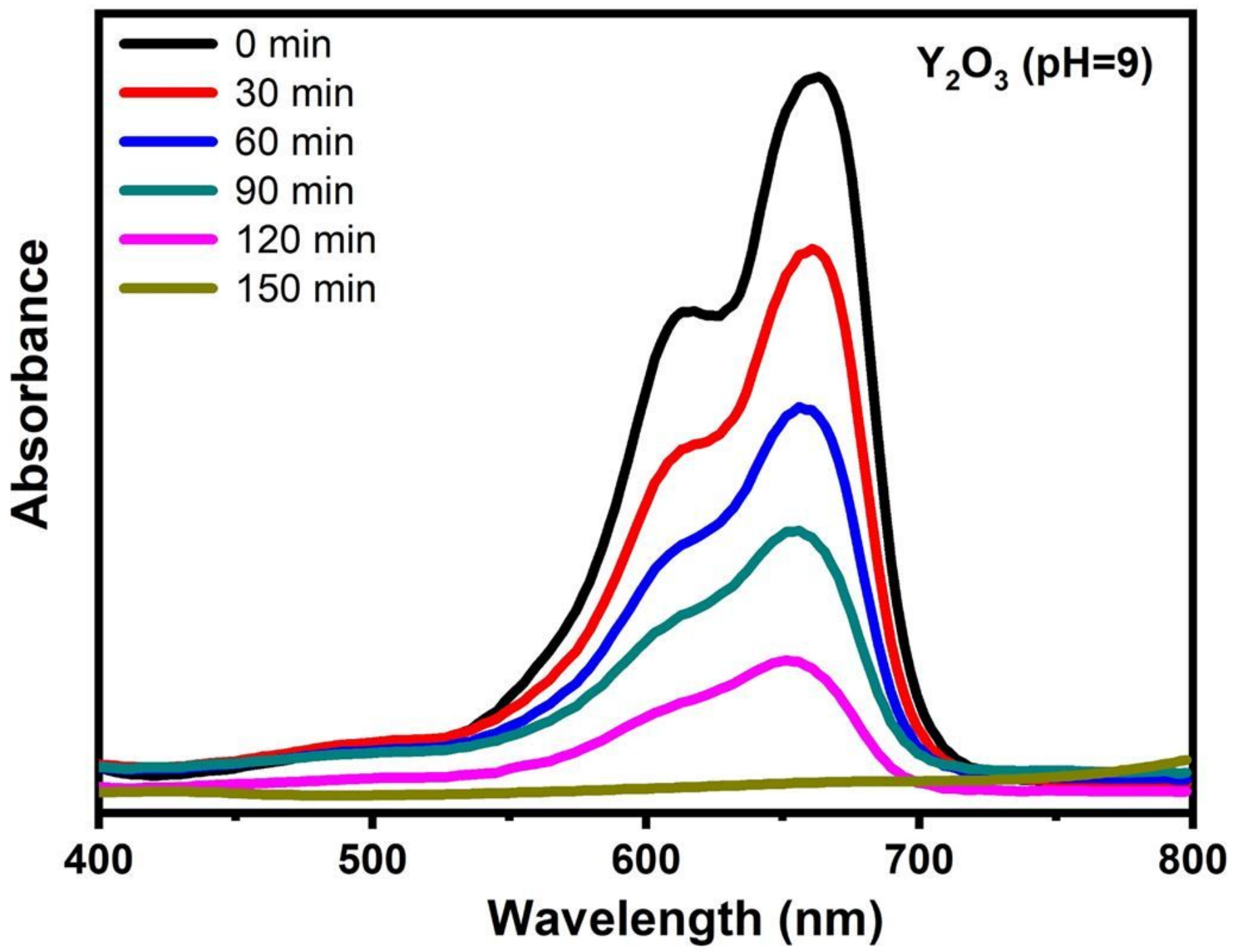

Figure 7

Absorbance spectrum of MB with $\mathrm{Y} 2 \mathrm{O} 3(\mathrm{pH}=9)$ sample under nature solar light irradiation 